\title{
Article \\ The Effect of Different Frying Methods and the Addition of Potassium Aluminum Sulfate on Sensory Properties, Acrylamide, and Oil Content of Fried Bread (Youtiao)
}

\author{
Yung-Shin Shyu ${ }^{1}$, Jean-Yu Hwang ${ }^{2}$, Shih-Ting Shen ${ }^{3}$ and Wen-Chieh Sung ${ }^{3,4, *(\mathbb{D}}$ \\ 1 Department of Baking Technology and Management, National Kaohsiung University of Hospitality and \\ Tourism, Kaohsiung City 812301, Taiwan; tristar@mail.nkuht.edu.tw \\ 2 Department of Food Nutrition, Chung Hwa University of Medical Technology, Tainan 717302, Taiwan; \\ zhenyu@mail.hwai.edu.tw \\ 3 Department of Food Science, National Taiwan Ocean University, Keelung 202301, Taiwan; \\ tina2056432@gmail.com \\ 4 Center of Excellence for the Oceans, National Taiwan Ocean University, Keelung 202301, Taiwan \\ * Correspondence: sungwill@mail.ntou.edu.tw; Tel.: +886-2-24622192 (ext. 5129)
}

check for updates

Citation: Shyu, Y.-S.; Hwang, J.-Y.; Shen, S.-T.; Sung, W.-C. The Effect of Different Frying Methods and the Addition of Potassium Aluminum Sulfate on Sensory Properties, Acrylamide, and Oil Content of Fried Bread (Youtiao). Appl. Sci. 2021, 11, 549. https://doi.org/10.3390/ app11020549

Received: 17 December 2020 Accepted: 5 January 2021 Published: 8 January 2021

Publisher's Note: MDPI stays neutral with regard to jurisdictional clai$\mathrm{ms}$ in published maps and institutional affiliations.

Copyright: (C) 2021 by the authors. Licensee MDPI, Basel, Switzerland. This article is an open access article distributed under the terms and conditions of the Creative Commons Attribution (CC BY) license (https:// creativecommons.org/licenses/by/ $4.0 /)$.

\begin{abstract}
This study aims to compare traditional, vacuum, and electrostatic frying methods on the mitigation of acrylamide formation, and oil content with and without potassium aluminum sulfate in youtiao. The results obtained showed that the addition of potassium aluminum sulfate decreased $\mathrm{pH}$ and $79.88 \%$ acrylamide content in youtiao with traditional frying. Electrostatic frying and vacuum frying methods do not reduce acrylamide content and oil content of youtiao when compared to the traditional deep-frying method in this research. The present study indicated that the $\mathrm{pH}$ of youtiao with vacuum frying method increased from 5.87 to 6.49 without potassium aluminum sulfate addition. Youtiao with potassium aluminum sulfate fried by traditional deep-frying had higher flavor and appearance score and lower oil content than the electrostatic frying method. The results of this research could be a consideration for alternative slow acting aluminum acidulants, reducing oil adsorbing frying methods in future work.
\end{abstract}

Keywords: youtiao; potassium aluminum sulfate; electrostatic frying; vacuum frying; acrylamide

\section{Introduction}

Youtiao, a form of fried bread, is a deep-fried strip of dough that is a popular breakfast food in China, Indonesia, Malaysia, Myanmar, Singapore, Laos, and some south Asian countries. It is even on the breakfast menus at KFCs in China [1]. Aluminum containing slow acting acidulant is an indispensable raising agent in youtiao during the deep fat-frying process, giving the product a fluffy, crisp texture [1,2]. Many studies have demonstrated that chronic exposure to aluminum can have a negative effect on cardiac, hepatic, immune, nervous, reproductive, and skeletal system [3-8]. Food and Agriculture Organization of United Nations/World Health Organization, European Union, and Mainland China have provisionally recommended that a tolerable aluminum intake of 2, 1, and $100 \mathrm{mg} / \mathrm{per}$ $\mathrm{kg} /$ per week, respectively, is an acceptable level. During the process, acrylamide is formed. Acrylamide is also an undesirable product: it can be toxic in baked or fried carbohydrates, potentially affecting reproductive functions and genetic factors [9]. Various methods for the mitigation of acrylamide formation have been proposed. These include changing the heating methods, modifying the $\mathrm{pH}$, decreasing the reducing sugar content and sugar liberation during storage, optimizing the storage temperature, choosing the cultivar of the foodstuffs, fermentation to remove reducing sugar, replacing reducing sugars with sucrose, adding organic acids or divalent cations, using chitooligosaccharide competing amino acids to dilute the asparagine level, decreasing the free asparagine concentration by asparaginase, or substituting ammonium salts with baking powder [10-20]. Although many researchers 
have noted that fried food consumption is associated with increased health risks, and most consumers are aware of this, there is no sign that people who like fried food have stopped eating their favorites [21].

Some alternative frying technologies, such as electrostatic frying and vacuum frying, have been developed to produce healthier fried foods with less fat and acrylamide content. Electrostatic frying - a fryer equipped with a portable discharge plate at the bottom of the fryer-is marketed for its shorter frying time and lower oil uptake and acrylamide content than traditional deep-frying methods [22]. A vacuum fryer processes food at lower oil temperature, oxygen content, and pressure, and is designed to reduce browning reaction, oil content, and adverse effects on oil quality, and to preserve natural flavor and color [23]. Water in the fried food can be removed rapidly. The technology has also been used to mitigate acrylamide generation in potato chips [15]. Vacuum frying has been used to reduce the oil uptake of fried vegetables and fruits with no loss of desired flavor and texture [24,25]. To date, there has been little scientific research into the electrostatic fryer. The use of its discharge plate to create static waves could reduce frying time, improve thermal conductivity, and reduce oil uptake [26]. The aim of this study was to investigate the effect of the vacuum fryer, electrostatic fryer, and potassium aluminum sulfate on acrylamide content and oil uptake of youtiao.

\section{Materials and Methods}

\subsection{Youtiao Preparation}

The youtiao was prepared according to the recipe of a traditional breakfast restaurant, following the method by Li et al. [1] with slight modifications. For the recipe: $100 \mathrm{~g}$ bread flour was added with $1.5 \mathrm{~g}$ salt, $1.4 \mathrm{~g}$ sodium bicarbonate, $1.5 \mathrm{~g}$ ammonium bicarbonate, $1.25 \mathrm{~g}$ potassium aluminum sulfate, and $62.5 \mathrm{~mL}$ water. The mixture was kneaded for $6 \mathrm{~min}$ until a soft, elastic dough was formed. The dough was covered with polyethylene (PE) film (Nan Ya Plastic Corporation, New Taipei City, Taiwan) and conditioned at $22{ }^{\circ} \mathrm{C}$ for $45 \mathrm{~min}$, after which it was refrigerated at $7^{\circ} \mathrm{C}$ for $12 \mathrm{~h}$. When the dough was removed from the refrigerator, it was rolled out into strips of $8 \mathrm{~cm}$ long, $0.5 \mathrm{~cm}$ thick, and $3 \mathrm{~cm}$ wide. Two pieces at a time were stacked and pressed in the center with a chopstick. The stacked pieces were stretched to $16 \mathrm{~cm}$ from the two ends before frying, and were deep-fried at $180{ }^{\circ} \mathrm{C}$ for $4 \mathrm{~min}$ in the electric fryer (Model: WFT-8L, WISE Co. Ltd., Taipei, Taiwan), or in the electrostatic fryer with a discharge plate (DENBA Co., Ltd., Tokyo, Japan). The stretched and un-stretched dough were also vacuum fried at $120^{\circ} \mathrm{C}$ and $73.327 \mathrm{kPa}$ for $4 \mathrm{~min}$ (model: VF-5, Chin Ying Fa Mechanical Ind. Co., Ltd., Chang Hua Hsien, Taiwan). The youtiao samples were set aside to cool and for the excess oil to drain away. Then, the samples were sealed in PE bags and frozen at $-18^{\circ} \mathrm{C}$ until analysis.

The effect of potassium aluminum sulfate on the $\mathrm{pH}$ of the youtiao was measured following Navarro and Morales [27]. Ground youtiao (25 mg) were mixed with $20 \mathrm{~mL}$ of double distilled water and blended for $3 \mathrm{~min}$. This was set at an ambient temperature for $30 \mathrm{~min}$ and then filtered with Whatman No 1 filter paper before the $\mathrm{pH}$ analysis (pH510, Eutech Instruments Pty Ltd. Ayer Rajah Crescent, Singapore). The water activity was measured according to the method used by Zoulias et al. [28]. Three grams of a fried youtiao sample was put in the sample compartment of water activity meter (AQUALAB4TE, Meter Group, Inc., Pullman, WA, USA). The youtiao was analyzed for moisture and fat content according to Association of Official Analytical Chemists (AOAC) methods [29]. Moisture content was calculated by the ratio between weight loss of the fried youtiao and initial sample weight in a convection oven at $105^{\circ} \mathrm{C}$ for $24 \mathrm{~h}$ or until its weight became constant. Lipid content of fried youtiao was determined gravimetrically after Soxhlet lipid extraction by diethyl ether using a Tecator Soxtec System HT 1043 (Foss Analytical Co., Ltd., Hillerod, Denmark).

The specific volume was calculated by measuring the volume and weight of the youtiao using the sesame seed displacement method, described by Chen et al. [30]. Hardness of the youtiao was tested with the TA.XT2 Texture Analyzer (Stable Micro Systems 
Co. Ltd., Haslemere, UK) according to the methods of Ve'lez-Ruiz and Sosa-Morales [31]. A TA-XT2 Texture Analyzer with a $15 \mathrm{~mm}$ cylinder probe was used to compress samples. Samples were compressed at $1.7 \mathrm{~mm} / \mathrm{s}$ to $25 \%$ depth. The maximum force during compression was recorded. The test was performed and the average maximum force was reported as hardness in Newton (N) (TC-1800 MKII, Tokyo, Japan), according to the method used by Chen et al. [30].

Commission on Illumination (CIE) $\mathrm{L}^{*}, \mathrm{a}^{*}, \mathrm{~b}^{*}$ of fried youtiao was measured by a spectrocolorimeter (TC-1800 MK II, Tokyo, Japan) according to the method of Dinc et al. [32]. Standardization was done using a black cup and a white tile before testing. Color change $\Delta \mathrm{E}$ was calculated using the following equation:

$$
\Delta \mathrm{E}=\left(\left(\Delta \mathrm{L}^{*}\right)^{2}+\left(\Delta \mathrm{a}^{*}\right)^{2}+\left(\Delta \mathrm{b}^{*}\right)^{2}\right)^{1 / 2}
$$

where $\Delta \mathrm{L}^{*}=\mathrm{L}_{\text {sample }}^{*}-\mathrm{L}_{\text {control }}^{*} \Delta \mathrm{a}^{*}=\mathrm{a}_{\text {sample }}^{*}-\mathrm{a}^{*}$ control $\Delta \Delta \mathrm{b}^{*}=\mathrm{b}^{*}$ sample $-\mathrm{b}^{*}$ control.

The brown index (BI) was calculated using the following equation:

$$
\mathrm{BI}=100 \times(\mathrm{x}-0.31) / 0.17
$$

where $\mathrm{x}=\left(\mathrm{a}^{*}\right.$ sample $+1.75 \mathrm{~L}^{*}$ sample $) /\left(5.645 \mathrm{~L}^{*}\right.$ sample $+\mathrm{a}^{*}$ sample $-3.012 \mathrm{~b}^{*}$ sample $)$.

\subsection{Method for Extracting and Measuring Reducing Sugar and Acrylamide in Fried Bread Youtiao}

The quantitative determination of reducing sugars was measured by a dinitrosalicylic acid reducing sugar assay following the method of James [33]. Ground youtiao sample $(0.1 \mathrm{~g})$ was added to $10 \mathrm{~mL}$ of $1.5 \mathrm{M}$ sulfuric acid and heated for $20 \mathrm{~min}$ in a boiling water bath. Then, $10 \%$ sodium hydroxide $(12 \mathrm{~mL})$ was added after cooling. The mixture was filtrated and made up to $100 \mathrm{~mL}$ with distilled, deionized water. Standard glucose solution was prepared in the assay for reducing sugars.

Youtiao samples were ground with a pulverizer (D3V-10, Yu Chi Machinery Co., Ltd., Chang Hua, Taiwan) and a $1 \mathrm{~g}$ sample was put into a $50 \mathrm{~mL}$ centrifuge tube. Deionized distilled water $(9 \mathrm{~mL})$ and $1 \mathrm{~mL}$ hexane was added, and the solution was mixed in a reciprocal shaker bath for $60 \mathrm{~min}$. The mixture was centrifuged at $9000 \mathrm{r} / \mathrm{min}$ for $20 \mathrm{~min}$ at $5{ }^{\circ} \mathrm{C}$. The supernatant was filtered through a nylon filter $(0.45 \mu \mathrm{m})$. The hdrophilic lipophilic balance (HLB)/mixed-mode cation exchange cartridge (MCX) cartridge was conditioned with $5 \mathrm{~mL}$ and $3 \mathrm{~mL}$ of methanol followed by $5 \mathrm{~mL}$ and $3 \mathrm{~mL}$ of deionized distilled water, respectively. The filtrate $(3 \mathrm{~mL})$ was passed through the Oasis HLB/MCX cartridge to absorb acrylamide and was then discarded. The cartridge was washed with $3.5 \mathrm{~mL}$ of deionized distilled water; the first $0.5 \mathrm{~mL}$ of filtrate was discarded, while the remaining $3.0 \mathrm{~mL}$ of eluent was collected in a brown glass tube. The eluent was concentrated under vacuum for high-performance liquid chromatography (HPLC) analysis.

Acrylamide concentrations of the youtiao were determined using the HPLC method of Barber et al. [34]. The HPLC system (D2000) consisted of an L-2130 pump, L-2400 detector, L-2300 column oven and an L-2200 autosampler (Merck, Hitachi, Kent, UK). The separation of acrylamide was achieved with a Capcell Pak C18 AQS5 column ( $5 \mu \mathrm{m}$, $4.6 \mathrm{~mm} \times 250 \mathrm{~mm}$ ) (Shiseido, Tokyo, Japan) as per the methods used by Chang et al. [35] using $25^{\circ} \mathrm{C}$ deionized distilled water at a flow rate of $0.7 \mathrm{~mL} / \mathrm{min}$ (mobile phase; $100 \%$ double distilled water; injection volume: $20 \mu \mathrm{m}$ ). The $400 \mu \mathrm{L}$ sample was spiked with $100 \mu \mathrm{L}$ of ${ }^{13} \mathrm{C}_{3}$-labeled acrylamide with $0.5 \mathrm{~mL}$ of double distilled water. The acrylamide elute $(2 \mu \mathrm{L})$ of HPLC was injected into an MS detector (mobile phase: (a) $0.1 \%(v / v)$ formic acid/water; (b) $0.1 \%(v / v)$ formic acid / methanol; source temperature: $600{ }^{\circ} \mathrm{C}$; electrospray capillary voltage; $5.5 \mathrm{kV}$; collision energy: $30 \mathrm{~V}$ ). Data acquisition was performed using the selected ion monitoring mode. The ions monitored in the sample were $\mathrm{m} / z 72.04$ for acrylamide and $m / z 75.04$ for ${ }^{13} C_{3}$-labeled acrylamide. Full scan analyses were performed in the mass range 50-200. The acrylamide calibration curve was built in the range of $1875-30,000 \mathrm{ng} / \mathrm{mL}$. 


\subsection{Sensory Evaluation}

Sensory evaluation of the youtiao was conducted by means of an untrained consumer ranking test: samples were served to 90 untrained panelists aged between 15 and 56 who were asked to evaluate color, texture, appearance, flavor, and overall acceptability, from " 1 = strongly like" to " $4=$ strongly dislike". Samples coded with three random digits were given to the panelists. Each data point from the sensory analysis represents the ranking mean of 90 panelists.

\subsection{Statistical Analysis}

The data were analyzed with the SPSS statistics program for Windows version 12 (SPSS Inc., Chicago, IL, USA). The ranking test for the color, texture, appearance, flavor, and overall acceptability of youtiao was carried out using Analysis of variance (ANOVA) and Duncan's multiple range tests to test differences between treatments at 95\% significance level $(p<0.05)$. Linear correlation between different test results were estimated by Pearson correlation analysis at a $p<0.05$ significance level.

\section{Results and Discussion}

Figure 1 shows the appearance of youtiao with traditional deep-frying, by electrostatic frying and by vacuum frying, with and without potassium aluminum sulfate.
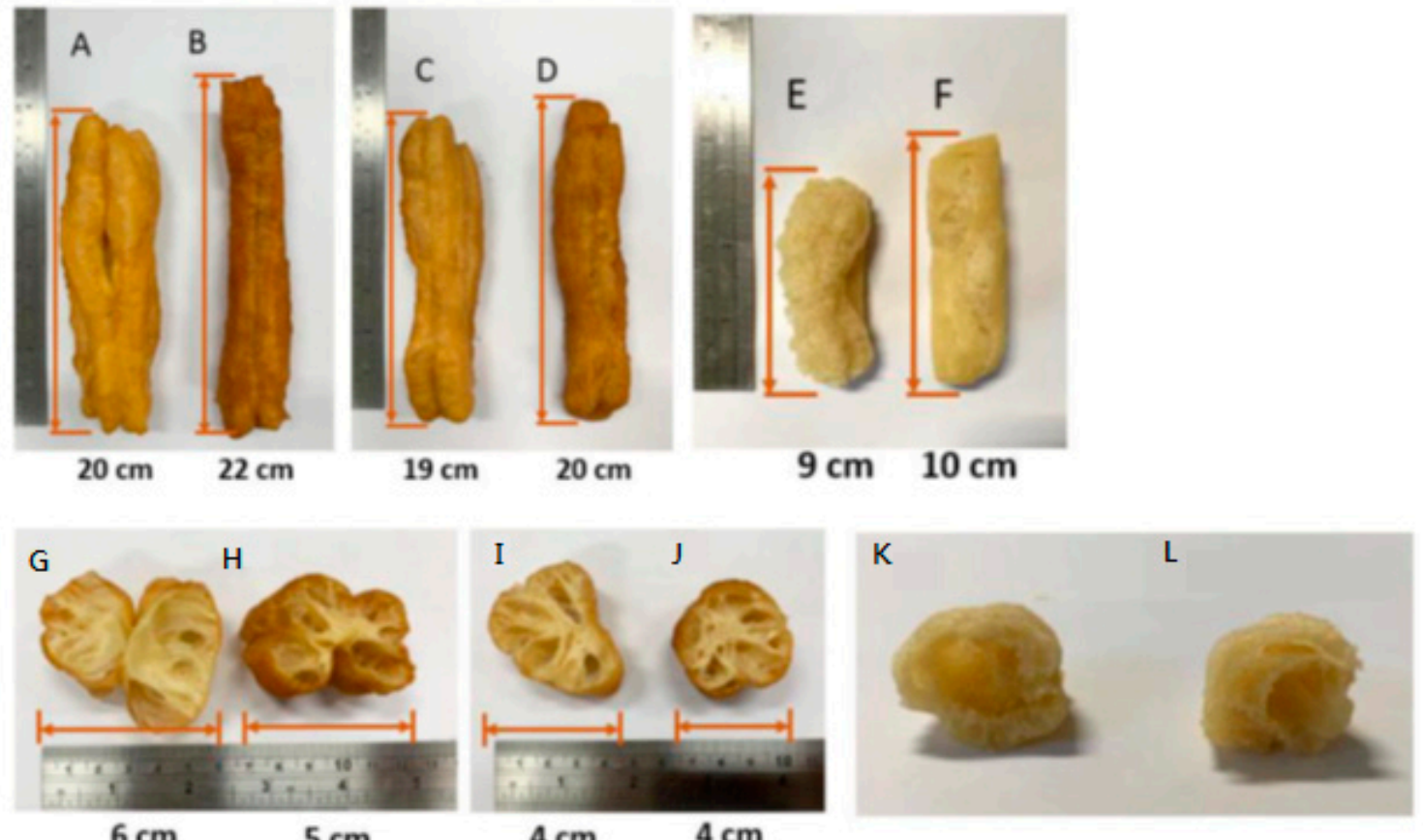

Figure 1. Appearance of fried bread youtiao by traditional frying, electrostatic frying, and vacuum frying. (A) Control: traditional frying + sodium aluminum sulfate. (B) Traditional frying without adding sodium aluminum sulfate. (C) Electrostatic frying + sodium aluminum sulfate. (D) Electrostatic frying without adding sodium aluminum sulfate. (E) Vacuum frying + sodium aluminum sulfate without dough stretching before frying. (F) Vacuum frying without adding sodium aluminum sulfate without dough stretching before frying. (G) Cross section: traditional frying + sodium aluminum sulfate. (H) Cross section: traditional frying without adding sodium aluminum sulfate. (I) Cross section: electrostatic frying + sodium aluminum sulfate. (J) Cross section: electrostatic frying without adding sodium aluminum sulfate. (K) Cross section: vacuum frying + sodium aluminum sulfate. (L) Cross section: vacuum frying without adding sodium aluminum sulfate.

Figure $1 \mathrm{~A}, \mathrm{C}$ indicate that there is no significant difference in appearance between deepfrying (Figure 1A) and electrostatic frying (Figure 1C). The youtiao have darker appearance without potassium aluminum sulfate addition after frying (Figure 1B,D) compared to the control (Figure 1A) and when fried in the electrostatic fryer (Figure 1C). In cross section, 
the deep-fried youtiao (Figure 1G,H) seems to have risen more than when electrostatically fried (Figure 1I,J). Vacuum-fried youtiao did not hold its structure during centrifugation to remove oil and broke into pieces. The appearance of the vacuum-fried youtiao (Figure 1E,F) at $120^{\circ} \mathrm{C}$ is subjectively lighter than that fried by the traditional (Figure $1 \mathrm{~A}$ ) and electrostatic (Figure 1C) methods. The results show that youtiao fried at a lower temperature $\left(120^{\circ} \mathrm{C}\right)$ for $4 \mathrm{~min}$ would not incur as strong Maillard reaction as deep-fried (Figure 1A) and the electrostatic (Figure 1C) method at $180{ }^{\circ} \mathrm{C}$ for $4 \mathrm{~min}$. The dough that was not stretched before vacuum frying showed rising in its width but not in its length (Figure 1E) when compared with the control (Figure 1A). The appearance of vacuum fried youtiao showed no difference (Figure 1E,K) whether or not potassium aluminum sulfate was added (Figure 1F,L). Therefore, vacuum frying should be used when products are expected to be lighter in color. The results show that potassium aluminum sulfate might react with sodium bicarbonate at temperatures higher than $120^{\circ} \mathrm{C}$ (Figure 1).

Table 1 shows that the $\mathrm{pH}$ of youtiao with potassium aluminum sulfate frying in vacuum fryer is lower than without potassium aluminum sulfate addition $(p<0.05)$. Potassium aluminum sulfate is a slow acting acidulant; it may react with sodium bicarbonate at $180^{\circ} \mathrm{C}$ and release carbon dioxide to raise the crumb after the youtiao crust forming. The youtiao samples without potassium aluminum sulfate addition, the $\mathrm{pH}$ of youtiao is higher than that of potassium aluminum sulfate is added. Therefore, more Maillard reaction might occur with deep-frying (Figure 1B) and electrostatic frying (Figure 1D) at a higher $\mathrm{pH}$ than with the addition of potassium aluminum sulfate (Figure 1A,C). Moreover, the appearance of the youtiao crust of samples B and D in Figure 1 is darker than that of Sample A and C. The Maillard reaction associated with the decreased solution $\mathrm{pH}$ when comparing trials, including acetic acid, formic acid, glyoxal, and pyruvaldehyde [36]. There was also less Maillard reaction in frying at lower temperatures $\left(120^{\circ} \mathrm{C}\right.$; vacuum frying) (Figure $1 \mathrm{E}, \mathrm{F}, \mathrm{K}, \mathrm{L}$ ) than that of traditional deep-frying and electrostatic frying $\left(180^{\circ} \mathrm{C}\right)$. Table 1 shows that youtiao fried in a vacuum fryer had significantly lower water activity than deep-fried youtiao and electrostatic frying (Table 1). This might be due to more moisture loss during the vacuum frying processes, which induced greater oil absorption in the sample (Table 1 and Figure 2). The moisture content of the traditional deep-frying youtiao was $22.93 \%$ (Table 1), which was similar to the moisture content of youtiao reported by Li et al. (19.38-32.61\%) [1]. Differences in moisture and fat content between youtiao, with and without potassium aluminum sulfate, are possibly due to the replacement of water with oil, following the evaporation process during the different frying methods. The hardness of youtiao was not influenced by the methods of deep-fried youtiao and electrostatic frying.

Table 1. Comparison of different frying methods for moisture, water activity, specific volume, and hardness * of fried bread youtiao.

\begin{tabular}{|c|c|c|c|c|c|c|}
\hline Treatments & Fat Content $* *(\%)$ & Moisture (\%) & Water Activity & $\mathrm{pH}$ & $\begin{array}{l}\text { Specific } \\
\text { Volume }\end{array}$ & Hardness (N) \\
\hline Control & $13.36 \pm 4.05^{\mathrm{a}}$ & $22.93 \pm 4.82^{\mathrm{a}}$ & $0.87 \pm 0.02^{\mathrm{a}}$ & $6.36 \pm 0.08^{b c}$ & $4.19 \pm 0.58^{\mathrm{a}}$ & $3.56 \pm 1.17^{\mathrm{ab}}$ \\
\hline $\operatorname{Tn} \mathrm{A}$ & $17.41 \pm 4.14^{\mathrm{a}}$ & $20.85 \pm 1.68^{a}$ & $0.87 \pm 0.02^{\mathrm{a}}$ & $6.58 \pm 0.15^{c}$ & $4.98 \pm 0.51^{\mathrm{b}}$ & $2.74 \pm 1.64^{\mathrm{a}}$ \\
\hline EA & $21.26 \pm 4.66^{\mathrm{ab}}$ & $19.71 \pm 3.31^{\mathrm{a}}$ & $0.88 \pm 0.03^{a}$ & $6.23 \pm 0.13^{a}$ & $4.16 \pm 0.80^{\mathrm{a}}$ & $4.97 \pm 2.36^{b}$ \\
\hline EnA & $20.16 \pm 3.98^{a b}$ & $19.87 \pm 1.71^{\mathrm{a}}$ & $0.89 \pm 0.01^{\mathrm{a}}$ & $6.62 \pm 0.06^{\mathrm{a}}$ & $3.63 \pm 0.27^{\mathrm{a}}$ & $4.27 \pm 1.15^{\mathrm{ab}}$ \\
\hline VA & $20.73 \pm 4.64^{\mathrm{a}}$ & $14.96 \pm 13.91^{a}$ & $0.33 \pm 0.02^{b}$ & $5.87 \pm 0.0^{\mathrm{d}}$ & ND & $3.71 \pm 1.71^{\mathrm{ab}}$ \\
\hline VnA & $25.18 \pm 0.75^{b}$ & $18.12 \pm 13.84^{\mathrm{a}}$ & $0.30 \pm 0.04^{b}$ & $6.49 \pm 0.0^{\mathrm{ab}}$ & ND & $6.35 \pm 3.37^{b}$ \\
\hline
\end{tabular}

* Expressed as mean \pm standard deviation. (Control $n=5$; TnA $n=5$; EA $n=5$; EnA $n=5$; VA $n=2$; VnA $n=2$ ); Values followed by the different letter ${ }^{\mathrm{a}-\mathrm{d}}$ within each column are significantly different $(p<0.05)$. N.D: mean not detected due to the youtiao is broken. Control: Traditional frying + potassium aluminum sulfate; TnA: Traditional frying without adding potassium aluminum sulfate; EA: Electrostatic frying + potassium aluminum sulfate; EnA: Electrostatic frying without adding potassium aluminum sulfate; VA: Vacuum frying + potassium aluminum sulfate; VnA: Vacuum frying without adding potassium aluminum sulfate. ${ }^{* *}$ Dry weight basis. 


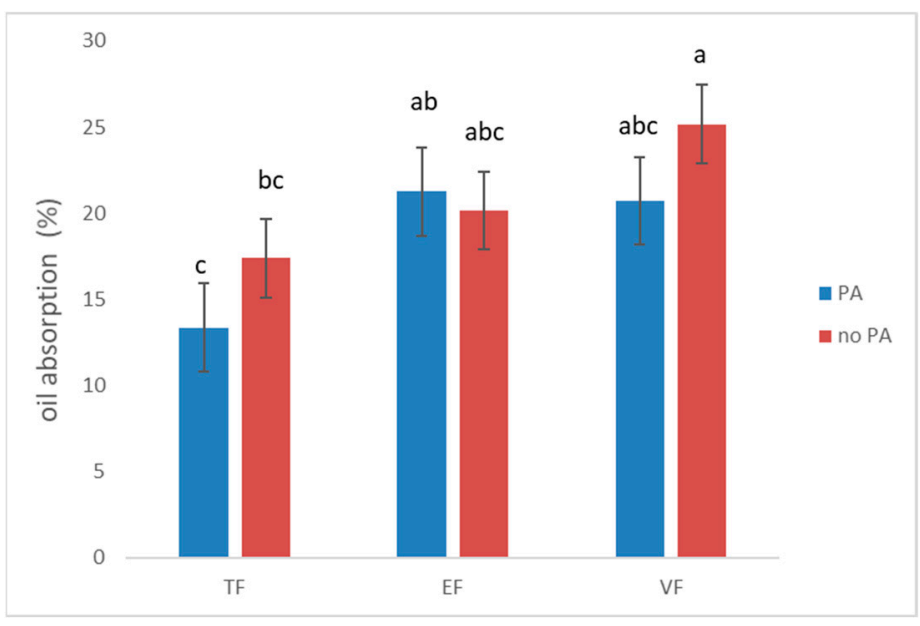

Figure 2. Effect of traditional frying, electrostatic frying, and vacuum frying on the oil content of fried bread youtiao. TF: traditional frying; EF: electrostatic frying; VF: vacuum frying; PA: sodium aluminum sulfate addition; no PA: without sodium aluminum sulfate addition. ${ }^{\mathrm{a}-\mathrm{c}}$ Indicate significant difference between different treatments.

Figure 2 shows the fat content of youtiao when fried by different methods. The control group (deep-frying) with potassium aluminum sulfate had an oil content of $13.36 \%$ while the youtiao fried by the vacuum frying methods had a higher oil content (20.73\%) (Figure 2). Fang et al. reported no difference in mass transfer, moisture loss, oil uptake, specific volume, hardness, color, and microstructure between traditional deep-frying and electrostatic fried fish skins [26].

Table 2 shows that youtiao without potassium aluminum sulfate would not influence the objective CIE $\mathrm{L}^{*}, \mathrm{a}^{*}$, and $\mathrm{b}^{*}$ values. However, the browning index (BI) of youtiao samples without potassium aluminum sulfate addition is higher than those of youtiao by different frying methods (Table 2). The difference in color $(\Delta \mathrm{E})$ and browning index when compared to the control sample indicates that, when the youtiao was vacuum fried, there were smaller $\Delta \mathrm{E}$ values compared with deep-frying and electrostatic frying methods (Table 2).

Table 2. Effect of traditional frying, electrostatic frying and vacuum frying methods on color values * of fried bread youtiao.

\begin{tabular}{cccccc}
\hline Treatments & $\mathbf{L}^{*}$ & $\mathbf{a}^{*}$ & $\mathbf{b}^{*}$ & $\mathbf{E}$ & $\mathbf{B I}$ \\
\hline Control & $75.23 \pm 4.88^{\mathrm{a}}$ & $-6.32 \pm 2.92^{\mathrm{a}}$ & $51.72 \pm 3.92^{\mathrm{a}}$ & 0 & 99.37 \\
TnA & $65.63 \pm 10.99^{\mathrm{a}}$ & $-2.24 \pm 2.22^{\mathrm{ab}}$ & $51.10 \pm 5.58^{\mathrm{a}}$ & 10.54 & 129.60 \\
\hline EA & $71.53 \pm 8.5^{\mathrm{a}}$ & $-6.54 \pm 2.68^{\mathrm{a}}$ & $49.67 \pm 4.30^{\mathrm{a}}$ & 4.24 & 101.62 \\
EnA & $69.81 \pm 8.44^{\mathrm{a}}$ & $-4.67 \pm 3.10^{\mathrm{ab}}$ & $49.65 \pm 4.27^{\mathrm{a}}$ & 6.03 & 108.15 \\
\hline VA & $76.59 \pm 0.26^{\mathrm{a}}$ & $-7.49 \pm 0.04^{\mathrm{a}}$ & $51.64 \pm 0.05^{\mathrm{a}}$ & 1.80 & 94.02 \\
VnA & $70.61 \pm 0.17^{\mathrm{a}}$ & $-5.70 \pm 0.04^{\mathrm{a}}$ & $51.23 \pm 0.10^{\mathrm{a}}$ & 4.69 & 108.22 \\
\hline
\end{tabular}

* Expressed as mean \pm standard deviation (Control $n=8 ; \operatorname{TnA} n=7 ;$ EA $n=7 ; \operatorname{EnA} n=7 ; \operatorname{VA} n=3 ; \operatorname{VnA} n=3$ ); Values followed by the different letter ${ }^{a, b}$ within each column are significantly different $(p<0.05)$. Control: Traditional frying + potassium aluminum sulfate; TnA: Traditional frying without adding potassium aluminum sulfate; EA: Electrostatic frying + potassium aluminum sulfate; EnA: Electrostatic frying without adding potassium aluminum sulfate; VA: Vacuum frying + potassium aluminum sulfate; VnA: Vacuum frying without adding potassium aluminum sulfate.

There are no significant differences in the reducing sugar content between the samples of traditional deep-frying method and electrostatic frying methods (Table 3), no matter the youtiao (with or without potassium aluminum sulfate addition). However, deep-fried youtiao without potassium aluminum sulfate contained more acrylamide (2095.2 ppb) than that of the control $(421.61 \mathrm{ppb})$ (Table 3) $(p<0.05)$. The results of a correlation analysis between the $\mathrm{pH}$ and acrylamide content of fried youtiao was positively correlated 
$(r=0.778 ; p<0.01)$. The acrylamide content and BI of fried youtiao were negatively correlated by the addition of potassium aluminum sulfate in the formulation $(r=-0.666$ and -0.457 , respectively; $p<0.05$ ). Acrylamide formation was confirmed having a negative correlation with the CIE $\mathrm{L}^{*}$ value of solution in a food model system at $180^{\circ} \mathrm{C}$ for $30 \mathrm{~min}$ heating [35]. Pedreschi et al. reported that the lower the moisture in potato and at higher frying temperature in the potato, the acrylamide formation in the fried product was higher [37]. The acrylamide content of vacuum fried youtiao, with potassium aluminum sulfate addition, is high, compared to traditional deep-frying and electrostatic frying youtiao $(p>0.05)$, although vacuum frying is fried at a lower temperature and the youtiao crust's color is lighter, which would generate less acrylamide. Although, the vacuum fryer removed more water during vacuum frying at lower frying temperatures and decreased water activity more effectively for fried products (Table 1), the acrylamide generation might be more at this processing condition. It needs further detailed experiments to clarify the hypothesis.

Table 3. Comparison of different frying methods for acrylamide and reducing sugar content ${ }^{*}$ of fried bread youtiao.

\begin{tabular}{ccc}
\hline Treatments & Acrylamide $(\mathbf{p p b})$ & Reducing Sugar (\%) \\
\hline Control & $421.61 \pm 48.63^{\mathrm{b}}$ & $11.5 \pm 1.15^{\mathrm{b}}$ \\
TnA & $2095.20 \pm 133.46^{\mathrm{a}}$ & $13.99 \pm 3.52^{\mathrm{ab}}$ \\
\hline EA & $667.37 \pm 42.98^{\mathrm{b}}$ & $12.04 \pm 1.17^{\mathrm{ab}}$ \\
EnA & $1147.13 \pm 676.84^{\mathrm{ab}}$ & $11.77 \pm 2.21^{\mathrm{ab}}$ \\
\hline VA & $1084.98 \pm 0.0^{\mathrm{ab}}$ & $13.33 \pm 0.0^{\mathrm{ab}}$ \\
VnA & $1530.26 \pm 0.0^{\mathrm{ab}}$ & $14.52 \pm 0.0^{\mathrm{a}}$ \\
\hline
\end{tabular}

* Expressed as mean \pm standard deviation (VA $n=2$; VnA $n=2$ ); Values followed by the different letter ${ }^{\mathrm{a}, \mathrm{b}}$ within each column are significantly different $(n=4 ; p<0.05)$. Control: Traditional frying + potassium aluminum sulfate; TnA: Traditional frying without adding potassium aluminum sulfate; EA: Electrostatic frying + potassium aluminum sulfate; EnA: Electrostatic frying without adding potassium aluminum sulfate; VA: Vacuum frying + potassium aluminum sulfate; VnA: Vacuum frying without adding potassium aluminum sulfate.

\section{Sensory Evaluation}

The results of youtiao (control) showed higher-ranking mean of 90 panelists for color (1.97), flavor (2.11), and overall acceptability (1.92). It indicates the panelists prefer the youtiao with the addition of potassium aluminum sulfate, using a traditional frying method. The ranking of the flavor of the youtiao control was significantly better than that of youtiao fried in the electrostatic fryer $(p<0.05)$. However, the color and appearance of youtiao with potassium aluminum sulfate addition was better than if potassium aluminum sulfate was not added, regardless of the frying method (Table 4). This may be because the youtiao is subjectively darker in appearance without the addition of potassium aluminum sulfate. The texture and flavor of traditional deep-fried youtiao is better than those of electrostatic frying (Table 4). The overall acceptability of the traditional frying youtiao was better than that of youtiao with no potassium aluminum sulfate addition and when fried in the electrostatic fryer (Table 4). 
Table 4. Effects of different frying methods and the addition of potassium aluminum sulfate on the sensory evaluation of fried bread youtiao.

\begin{tabular}{cccccc}
\hline \multirow{2}{*}{ Sample } & \multicolumn{3}{c}{ Sensory Score ${ }^{*}$} \\
\cline { 2 - 6 } & Color & Texture & Appearance & Flavor & Overall Acceptability \\
\hline Control & $1.97 \pm 0.91^{\mathrm{a}}$ & $2.34 \pm 1.09^{\mathrm{a}}$ & $2.23 \pm 1.24^{\mathrm{a}}$ & $2.11 \pm 1.03^{\mathrm{a}}$ & $1.92 \pm 0.91^{\mathrm{a}}$ \\
TnA & $3.16 \pm 1.0^{\mathrm{b}}$ & $2.22 \pm 1.20^{\mathrm{a}}$ & $2.92 \pm 1.07^{\mathrm{b}}$ & $2.77^{\mathrm{a}} \pm 1.18^{\mathrm{b}}$ & $2.62 \pm 1.06^{\mathrm{a}}$ \\
\hline EA & $1.97 \pm 1.02^{\mathrm{a}}$ & $2.74 \pm 1.46^{\mathrm{b}}$ & $1.93 \pm 0.83^{\mathrm{a}}$ & $2.44 \pm 0.94^{\mathrm{b}}$ & $2.19 \pm 1.00^{\mathrm{a}}$ \\
EnA & $2.9 \pm 0.98^{\mathrm{b}}$ & $2.60 \pm 1.02^{\mathrm{b}}$ & $2.99 \pm 0.88^{\mathrm{b}}$ & $2.71 \pm 1.18^{\mathrm{b}}$ & $3.21 \pm 0.99^{\mathrm{b}}$ \\
\hline
\end{tabular}

${ }^{*}$ Expressed as mean \pm standard deviation $(n=90)$. Values followed by the different letter ${ }^{\mathrm{a}, \mathrm{b}}$ within each column are significantly different $(p<0.05 ; n=90) .1$ = strongly like; 4 = strongly dislike; Control: Traditional frying + potassium aluminum sulfate; TnA: Traditional frying without adding potassium aluminum sulfate; EA: Electrostatic frying + potassium aluminum sulfate; EnA: Electrostatic frying without adding potassium aluminum sulfate.

\section{Conclusions}

In this study, the effects of potassium aluminum sulfate and different frying methods were used to compare the potential reduction of acrylamide and oil content of youtiao and on the sensory properties of fried youtiao. Theoretically, potassium aluminum sulfate is a slow acting acidulant and can react with sodium bicarbonate at high temperatures to release $\mathrm{CO}_{2}$. The youtiao without potassium aluminum sulfate addition is subjectively darker in appearance and generates high acrylamide amount. This may be because a greater Maillard reaction occurs at the higher $\mathrm{pH}$, inducing a darker color on the surface of the youtiao. Vacuum frying can remove more moisture from the youtiao at a lower temperature $\left(120^{\circ} \mathrm{C}\right)$ and form lower water activity of fried youtiao $(p<0.05)$. However, the youtiao was light in color due to less of a Maillard reaction occurring. Moreover, more oil was absorbed into the crumb of the youtiao and generated a high amount of acrylamide. Vacuum frying and electrostatic frying methods did not significantly reduce oil content and improve the texture and appearance of fried youtiao. Therefore, vacuum frying and electrostatic frying techniques are not recommended for youtiao production even though electrostatic frying is a new technique for reducing frying time and oil absorption in products. The electrostatic plate accelerates the moisture evaporation from the product and causes more oil to be absorbed. The electrostatic fried youtiao was not as crispy as that of the traditional deep-fried youtiao because the youtiao expands less and absorbs ammonia, negatively affecting the flavor of the product in sensory evaluation. A more suitable slow acting acidulant without aluminum, such as sodium acid pyrophosphate, dicalcium phosphate, or glucano delta lactone is expected, and will be investigated for its use in youtiao in the future.

Author Contributions: Conceptualization, Y.-S.S., J.-Y.H., and S.-T.S.; methodology, Y.-S.S. and S.-T.S.; writing — original draft preparation, Y.-S.S. and W.-C.S.; writing-review and editing, W.-C.S.; visualization, S.-T.S.; supervision, W.-C.S.; project administration, Y.-S.S.; funding acquisition, Y.-S.S. and J.-Y.H., S.-T.S., and W.-C.S. designed the study. S.-T.S. and Y.-S.S. performed the experiments and J.-Y.H. analyzed the data. W.-C.S. wrote the paper with input from all authors. All authors have read and agreed to the published version of the manuscript.

Funding: This research received no external funding.

Data Availability Statement: The data presented in this study are available in this article.

Conflicts of Interest: The authors declare no conflict of interest.

\section{References}

1. Li, G.; Wu, S.; Zeng, J.; Wang, L.; Yu, W. Effect of frying and aluminum on the levels and migration of parent and oxygenate PAHs in a popular Chinese fried bread youtiao. Food Chem. 2016, 209, 123-130. [CrossRef] [PubMed]

2. Li, G.; Zhao, X.; Wu, S.; Hua, H.; Wang, Q.; Zhang, Z. Dietary exposure to aluminum in the popular Chinese fried bread youtiao. Food Addit. Contam. Part A 2017, 34, 972-979. [CrossRef] [PubMed] 
3. Costello, S.; Eisen, E.A.; Brown, D.; Hammond, S.K.; Cullen, M. Incident ischemic heart disease and occupational exposure to particulate matter in aluminum manufacturing workers. Am. J. Epidmiol. 2012, 175, S139. [CrossRef]

4. Di Paolo, C.; Reverte, I.; Colomina, M.T.; Domingo, J.I.; Gomez, M. Chronic exposure to aluminum and melatonin through the diet: Neurobehavioral effects in a transgenic mouse model of Alzheimer disease. Food Chem. Toxicol. 2014, 69, 320-329. [CrossRef] [PubMed]

5. Li, X.; Hu, C.; Zhu, Y.; Sun, H.; Li, Y.; Zhang, Z. Effects of aluminum exposure on bone mineral density, mineral, and trace elements in rats. Biol. Trace Elem. Res. 2011, 143, 378-385. [CrossRef]

6. Malloux, R.J.; Lemire, J.; Appanna, V.D. Hepatic response to aluminum toxicity: Dyslipidemia and liver diseases. Exp. Cell Res. 2011, 317, 2231-2238. [CrossRef]

7. Zhu, Y.Z.; Liu, D.W.; Liu, Z.Y.; Ki, Y.F. Impact of aluminum exposure on the immune system: A mini review. Environ. Toxicol. Pharmacol. 2013, 35, 82-87. [CrossRef]

8. Zhu, Y.Z.; Sun, H.; Fu, Y.; Wang, J.; Song, M.; Li, M.; Li, Y.F.; Miao, L.G. Effects of subchronic aluminum chloride on spermatogenesis and testicular enzymatic activity in male rats. Life Sci. 2014, 102, 36-40. [CrossRef]

9. Lineback, D.R.; Coughlin, J.R.; Stadler, R.H. Acrylamide in Foods: A review of the science and future considerations. Annu. Rev. Food Sci. Technol. 2012, 3, 15-35. [CrossRef]

10. Amrein, T.M.; Schonbachler, B.; Escher, F.; Amado, R. Acrylamide in gingerbread: Critical factors for formation and possible ways for reduction. J. Agric. Food Chem. 2004, 52, 4282-4288. [CrossRef]

11. Baardseth, P.; Blom, H.; Skrede, G.; Mydland, L.T.; Skrede, A.; Slinde, E. Lactic acid fermentation reduces acrylamide formation and other Maillard reactions in French fries. J. Food Sci. 2006, 71, C28-C33. [CrossRef]

12. Biedermann, M.; Grob, K. Model studies on acrylamide formaition in potato, wheat flour and corn starch; ways to reduce acrylamide contents in bakery ware. Mitt. Lebensm. Hyg. 2003, 94, 406-422.

13. Brathen, E.; Kita, A.; Knutsen, S.H.; Wicklund, T. Addition of glycine reduces the content of acrylamide in cereal and potato products. J. Agric. Food Chem. 2005, 53, 3259-3264. [CrossRef] [PubMed]

14. Fiselier, K.; Grob, K. Legal limit for reducing sugars in prefabricates targeting $50 \mathrm{~g} / \mathrm{kg}$ acrylamide in French fries. Eur. Food Res. Technol. 2005, 220, 451-458. [CrossRef]

15. Granda, C.; Moreira, R.G.; Tichy, S.E. Reduction of acrylamide formation in potato chips by low-temperature vacuum frying. J. Food Sci. 2004, 69, E405-E411. [CrossRef]

16. Jung, M.Y.; Choi, D.S.; Ju, J.W. A novel technique for limitation of acrylamide formation in fried and baked corn chips and in French fries. J. Food Sci. 2003, 68, 1287-1290. [CrossRef]

17. Levine, R.A.; Smith, R.E. Sources of variability of acrylamide levels in cracker model. J. Agric. Food Chem. 2005, 53, 4410-4416. [CrossRef]

18. Pedreschi, F.; Kaack, K.; Granby, K. The effect of asparaginase on acrylamide formation in French fries. Food Chem. 2008, 109, 386-392. [CrossRef]

19. Chang, Y.W.; Zeng, X.Y.; Sung, W.C. Effect of chitooligosaccharide and different low molecular weight chitosans on the formation of acrylamide and 5-hydroxymethylfurfural and Maillard reaction products in glucose/fructose-asparagine medel systems. LWT-Food Sci. Technol. 2020, 119, 108879. [CrossRef]

20. Huang, W.; Yu, S.; Zou, Q.; Tilley, R. Effects of frying condtions and yeast fermentation on the acrylamide content in you-tiao, a traditional Chinese, fried, twisted dough-roll. Food Res. Int. 2008, 41, 918-923. [CrossRef]

21. Sayon-Orea, C.; Bes-Rastrollo, M.; Basterra-Gortari, F.J.; Beunza, J.J.; Gatallar-Gastillon, P.; De la Fuente-Arrillaga, C.; MartinezGonzalez, M.A. Consumption of fried foods and weight gain in Mediterranean cohort: The SUN project. Nutr. Metab. Cardiovasc. Dis. 2013, 23, 144-150. [CrossRef]

22. DENBA Technology. Available online: http:/ / www.denba-global.com/en/ (accessed on 3 January 2021).

23. Shyu, S.L.; Hau, L.B.; Hwang, L.S. Effect of vacuum frying on the oxidative stability of oils. J. Am. Oil Chem. Soc. 1998, 75, 1393-1398. [CrossRef]

24. Andres-Bello, A.; Garcia-Segovia, P.; Martinez-Monzo, J. Vacuum frying: An alternative to obtain high-quality dried products. Food Eng. Rev. 2011, 3, 66-78. [CrossRef]

25. Su, Y.; Zhang, M.; Zhang, W.; Adhikari, B.; Yang, Z. Application of novel microwave-assisted vacuum frying to reduce the oil uptake and improve the quality of potato chips. LWT-Food Sci. Technol. 2016, 73, 490-497. [CrossRef]

26. Fang, M.; Huang, G.J.; Sung, W.C. Mass transfer and texture characteristics of fish skin during deep-fat frying, electrostatic frying, air frying and vacuum frying. LWT-Food Sci. Technol. 2021, 137, 110494. Available online: https://www.x-mol.com/ paperRedirect/1323384428045766656 (accessed on 2 January 2021). [CrossRef]

27. Navarro, M.; Morales, F.J. Effect of hydroxytyrosol and olive leaf extract on 1, 2-dicarbonyl compounds, hydroxymethylfurfural and advanced glycation endproducts in a biscuit model. Food Chem. 2007, 217, 602-609. [CrossRef]

28. Zoulias, E.I.; Oreopoulou, V.; Kounalaki, E. Effect of fat and sugar replacement on cookie properties. J. Sci. Food Agric. 2002, 82, 1637-1644. [CrossRef]

29. AOAC. Official Methods of Analysis of the Association of Official Analytical Chemists, 16th ed.; Sidney, W., Ed.; AOAC: Washington, DC, USA, 1998.

30. Chen, T.Y.; Luo, H.M.; Hsu, P.H.; Sung, W.C. Effects of calcium supplements on the quality and acrylamide content of puffed shrimp chips. J. Food Drug Anal. 2016, 24, 164-172. [CrossRef] 
31. Ve'lez-Ruiz, J.F.; Sosa-Morales, M.E. Evaluation of physical properties of dough of donuts during deep-fat frying at different temperatures. Int. J. Food Prop. 2003, 2, 341-353. [CrossRef]

32. Dinc, S.; Javidipour, I.; Ozbas, O.; Tekin, A. Utilization of zero-trans non-interesterified and interesterified shortenings in cookie production. J. Food Sci. Technol. 2014, 51, 365-370. [CrossRef]

33. James, C.S. Analytical Chemistry of Foods; Chapman and Hall: New York, NY, USA, 1995.

34. Barber, D.S.; Hunt, J.R.; Ehrich, M.F.; Lehning, E.J.; LoPachin, R.M. Metabolism, toxicokinetics and hemoglobin adduct formation in rats following subacute and subchronic acrylamide dosing. Neurotoxicology 2001, 22, 341-353. [CrossRef]

35. Chang, Y.W.; Sung, W.C.; Chen, J.Y. Effect of different molecular weight chitosans on the mitigation of acrylamide formation and the functional properties of the resultant Maillard reaction products. Food Chem. 2016, 199, 581-589. [CrossRef] [PubMed]

36. Martins, S.I.; Van Boekel, M.A. A kinetic model for the glucose/glycine Maillard reaction pathways. Food Chem. 2005, 90, 257-269. [CrossRef]

37. Pedreschi, F.; Moyano, P.; Kaock, K.; Granby, K. Colour changes and acrylamide formation in fried potato slices. Food Res. Int. 2005, 38, 1-9. [CrossRef] 